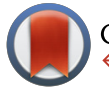

CrossMark \& click for updates

Cite this: Med. Chem. Commun., 2016, 7, 1082

\title{
Expanding the chemical space of hydrophobic pharmacophores: the role of hydrophobic substructures in the development of novel transcription modulators $\dagger$
}

\author{
Shinya Fujii
}

Interactions between biologically active compounds and their targets often involve hydrophobic interactions, and hydrophobicity also influences the pharmacokinetic profile. Nevertheless, comparatively less attention has been given to the utilization of hydrophobic substructures other than hydrocarbons in the design of biologically active compounds. Herein the author reviews the development of novel transcription modulators incorporating three types of substructures, i.e., silyl and germyl functionalities, hydrophobic boron clusters, and cyclopentadiene-based organometallic sandwich compounds, as hydrophobic components.

Received 8th January 2016 Accepted 18th April 2016

DOI: $10.1039 / \mathrm{c} 6 \mathrm{md} 00012 \mathrm{f}$

www.rsc.org/medchemcomm

an important feature of nuclear signal-regulating compounds, such as nuclear receptor ligands and other transcription factor modulators.

The author reviews herein the development of novel transcription modulators, focusing on the introduction of three classes of hydrophobic substructures: silyl and germyl functionalities, hydrophobic boron clusters, and cyclopentadienebased organometallic sandwich compounds.

\section{Alkylsilane and other group 14 atom- containing functionalities}

Carbon-silicon exchange (sila-substitution) of hydrocarbons is a widely utilized strategy for the development of biologically active compounds bearing novel hydrophobic substructures. ${ }^{2-5}$ Regarding their application towards transcription modulators,

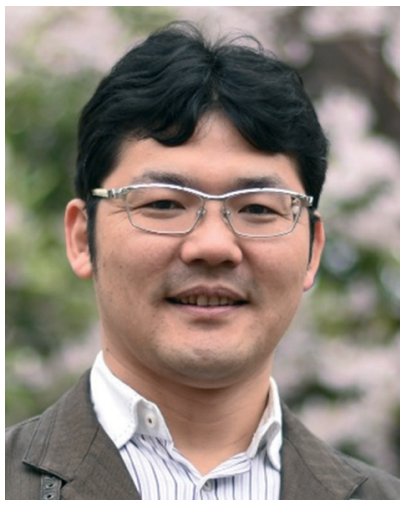

Shinya Fujii
Shinya Fujii was born in Toyota City, Japan, in 1977. He received his PhD from The University of Tokyo. He served as a researcher in Kyowa Hakko Kogyo Co., Ltd. (2002-2004), a research associate at Tokushima-Bunri University (2004-2007) and an assistant professor at Tokyo Medical and Dental University (20072013), and he is currently a lecturer at The University of Tokyo. His research interests include medicinal chemistry and elemental chemistry focusing on the chemistry of hydrophobicity. 
silicon-containing retinoids, i.e. nuclear retinoic acid receptor (RARs) ligands, and rexinoids, i.e. retinoid $\mathrm{X}$ receptor (RXRs) ligands, have been intensively investigated. The key structural features of retinoids and rexinoids are a carboxyl group and a hydrophobic pharmacophore, and various retinobenzoic acids have been developed (Fig. 1). ${ }^{6}$

Carboxylic acid derivatives of benzanilide (Am compounds) ${ }^{7}$ and chalcone (Ch compounds) ${ }^{8}$ by Shudo and co-workers are potent RAR ligands. Hydrophobic substituents on the benzoyl moiety significantly affect the activity of the compounds, and sila-substitution of the hydrophobic substructure effectively enhances the activity. Replacement of the two tert-butyl groups of Am555 (1) with trimethylsilyl groups, giving Am555S (2, TAC101), i.e. di-sila-substitution of Am555, resulted in approximately ten-fold enhancement of the biological activity. Silasubstitution of chalcone derivative Ch55 (3) to afford silicon derivative Ch55S (4) also increased the activity. In addition, germa-substituted Ch55G (5) is also more potent than Ch55. ${ }^{9}$ Am555S had been developed for treatment of advanced hepatocellular carcinoma (Fig. 2). ${ }^{10}$

etramethyltetrahydronaphthalene derivatives tamibarotene $(A m 80,6)^{11,12}$ and bexarotene $(12)^{13,14}$ are representative synthetic ligands for RAR and RXR, respectively, and have been approved for treatment of acute promyelocytic leukemia (APL) and cutaneous $\mathrm{T}$ cell lymphoma (CTCL), respectively. Tacke and co-workers have extensively investigated the disila-substituted derivatives of retinoids, rexinoids, and related compounds (Fig. 3). In the case of the RAR ligands, silasubstitution significantly affected the subtype selectivity. Silicon-containing RAR ligands 7 and 9 exhibited a potent activity toward RAR $\alpha$ with almost the same potency as the parent compounds 6 and 8, respectively, whereas silicon derivatives 7 and 9 exhibited a more potent activity toward RAR $\beta$ and RAR $\gamma .{ }^{15}$ Di-sila-substitution of stilbene-based pan-RAR agonist TTNPB (disila-TTNPB, 11) resulted in a pan-RAR agonistic activity with potency similar to that of the parent TTNPB (10). ${ }^{16}$ As for the RXR ligands, disila-bexarotene (13) exhibited a similar activity to the parent bexarotene (12), ${ }^{17}$ and dioxolane-based disila-SR11237 (15) also exhibited similar potency to the parent SR11237 (14). On the other hand, di-sila-substituted 17 was ten-fold more potent than the carbon analog, indane derivative 16. Crystal structure analysis suggested that enlargement of the hydrophobic bicyclic structure by incorporation of silicon atoms enables additional hydrophobic interactions between the compound and the receptor (PDBID: 2ZXZ for 16-hRXR $\alpha$ and 2XY0 for 17-hRXR $\alpha$ ). ${ }^{16,18}$

Disilacyclic compounds were also developed as ligands for retinoic acid receptor-related orphan receptor (RORs). Benzanilide derivative 19 inhibits the constitutive activity of

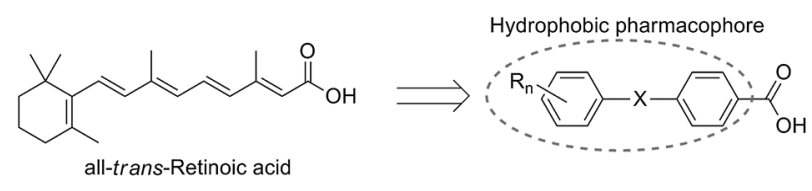

Fig. 1 Design scheme of retinobenzoic acids.

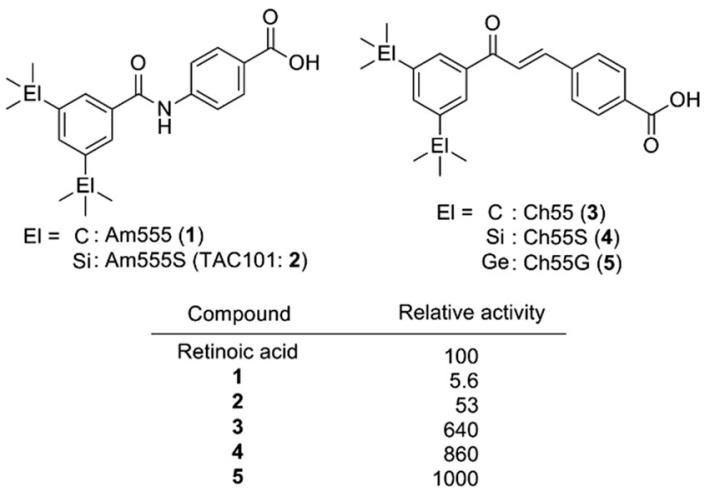

Fig. 2 Structure and biological activity of representative bis(trialkylsilyl) and bis(trialkylgermyl) retinobenzoic acid derivatives by Shudo et al.

$\operatorname{ROR} \alpha$ and $\operatorname{ROR} \gamma$, indicating that it acts as an inverse agonist toward these RORs, whereas the activity of the corresponding carbon analog 18 was significantly less potent than that of the silicon analog. Enlargement of the hydrophobic structure and change of the electrostatic potential are possible reasons for the greater potency of the silicon analog (Fig. 4). ${ }^{19}$

In addition to the case of retinoids such as 7 and 9, switching of selectivity was also observed in the case of the diphenylsilane derivatives. Diphenylpentane derivative LG190155 (22) was developed as a derivative of vitamin $\mathrm{D}$ receptor (VDR) agonist LG190178 (20), ${ }^{20}$ and exhibited a VDR agonistic activity and moderate androgen receptor (AR) antagonistic activity. ${ }^{21}$ Silasubstitution of the central carbon atom of these compounds, giving sila-LG190178 (21) and sila-LG190155 (23), resulted in significant loss of the VDR agonistic activity and increase of the AR antagonistic activity (Fig. 5). This VDR/AR selectivity switching can be attributed to enlargement of the skeletal structure. ${ }^{22}$

The characteristic properties of silicon- and germaniumcontaining derivatives such as Am555S (2) and compound 17 result at least partly from the change of inherent hydrophobicity compared with the corresponding carbon analogues. In order to understand the characteristics of silicon- and germaniumcontaining compounds, systematic determination of the hydrophobicity parameters of these heavier group 14 atomcontaining substituents was performed. With 4-substituted phenol as a fundamental structure, hydrophobicity parameters (i.e. $\log P_{\mathrm{o} / \mathrm{w}}$ values and Hansch-Fujita hydrophobic parameter $\pi$ ) of various alkylsilyl and alkylgermyl functionalities were determined. ${ }^{23}$ The silicon analogs exhibited larger $\log P_{\mathrm{o} / \mathrm{w}}$ values than the corresponding carbon analogs, with differences in the $\log P_{\mathrm{o} / \mathrm{w}}$ values of approximately 0.6. This difference in the $\log$ $P_{\mathrm{o} / \mathrm{w}}$ values between the silicon analogs and the corresponding carbon analogs was essentially independent of the alkyl substituents. On the other hand, the differences in the $\log P_{\mathrm{o} / \mathrm{w}}$ values between the silicon analogues and the corresponding germanium analogues were small (Fig. 6). This suggests that the difference in the hydrophobicity can be mainly attributed to the difference in the covalent radius of the central atom $(\mathrm{C}, 77 \mathrm{pm}$; Si, 117 pm; Ge, 122 pm).

The 4-substituted phenol structure is a pharmacophore of estrogen receptor (ER) ligands, and therefore these trialkylsilyl- 
<smiles>C[Si]1CC[Si](C)(C)c2cc(NC(=O)c3ccc(C(=O)O)cc3)ccc21</smiles>

$\mathrm{EI}=\mathrm{C}:$ Am80 (Tamibarotene: $\mathbf{6})$ Si : disila-Am80 (7)

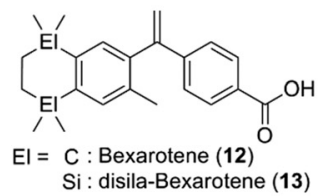<smiles>C[Si]1(C)CC[Si](C)(C)c2cc(C(=O)Nc3ccc(C(=O)O)cc3)ccc21</smiles>

$E I=C: A m 580(8)$ Si : disila-Am580 (9)

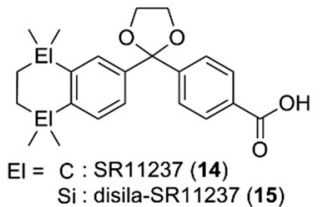

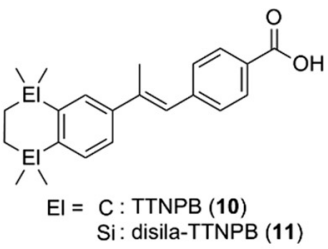

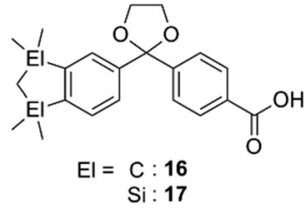

Fig. 3 Representative disilacyclic derivatives developed by Tacke et al. as RAR or RXR ligands.

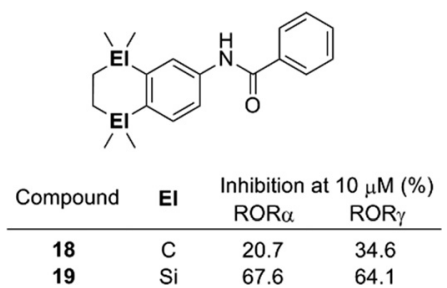

Fig. 4 Structure and biological activity of benzanilide-based ROR ligands.
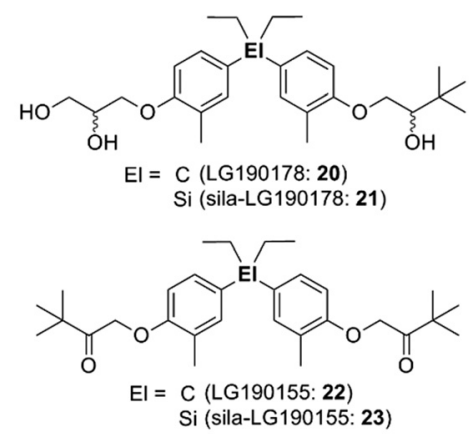

\begin{tabular}{ccccc} 
Compound & EI & $\begin{array}{c}\text { VDR } \\
\mathrm{PC}_{50}(\mu \mathrm{M})\end{array}$ & $\begin{array}{c}\mathrm{AR} \\
\mathrm{IC}_{50}(\mu \mathrm{M})\end{array}$ & $\begin{array}{c}\text { Selectivity } \\
\operatorname{VDR}\left(\mathrm{PC}_{50}\right) / \mathrm{AR}\left(\mathrm{IC}_{50}\right)\end{array}$ \\
\hline $\mathbf{2 0}$ & $\mathrm{C}$ & 0.14 & $>>10$ & $<0.014$ \\
$\mathbf{2 1}$ & $\mathrm{Si}$ & 0.92 & 6.8 & 0.14 \\
$\mathbf{2 2}$ & $\mathrm{C}$ & 4.6 & $>10$ & $<0.46$ \\
$\mathbf{2 3}$ & $\mathrm{Si}$ & $>30$ & 6.2 & $>4.8$
\end{tabular}

Fig. 5 Selectivity switching by Si/C exchange.

and trialkylgermylphenols should function as ER ligands. Evaluation of the estrogenic activity by means of an ER $\alpha$ dependent MCF-7 cell proliferation assay revealed that the silyl and germyl derivatives exhibited a more potent activity than the corresponding carbon analogs. For example, triethylsilylphenol 25 and triethylgermylphenol 26 showed $\mathrm{EC}_{50}$

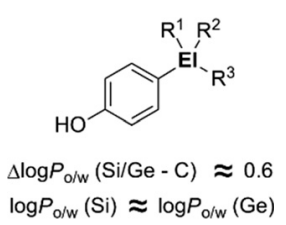

Fig. 6 Increase in hydrophobicity upon sila- and germa-substitution. values of 3.4 and $2.1 \mathrm{nM}$ (carbon analogue $24, \mathrm{EC}_{50}=23 \mathrm{nM}$ ) (Fig. 7). ${ }^{23}$ Thus, sila-substitution and germa-substitution are promising approaches to develop simple and potent bioactive compounds.

Recently, application of silyl groups, rather than simple sila-substitution (carbon-silicon exchange), has been proposed. The covalent radius of a silicon atom is larger than that of carbon, and therefore silyl groups could be geometrically equivalent to the diatomic substructure. Indeed, the diphenylsilane structure could function as an alternative to the $c i s$-stilbene core structure in the case of tubulin polymerization inhibitors, indicating that silyl groups could be a bioisostere of a cis-olefinic double bond. ${ }^{24}$ There are many biologically active compounds bearing cis-olefin, including various nuclear receptor modulators. A representative example is oleoylethanolamide (OEA), an endogenous ethanolamide lipid of the C18:1 fatty acid. OEA exhibits various biological activities including a peroxisome proliferator-activated receptor alpha (PPAR $\alpha$ ) agonistic activity. ${ }^{25}$ Molecular orbital calculation indicated that the distance ( $d$ in Fig. 8 ) in the silane is similar to that of the cis-olefin, whereas the distance in the corresponding alkane is significantly shorter. Thus, replacement of the cis-olefin of fatty acid derivatives with a silyl functionality would be a reasonable conversion (Fig. 8). As a result of structural development, it was found that ethanolamide lipid 27a, containing a silyl moiety instead of a cis-olefinic

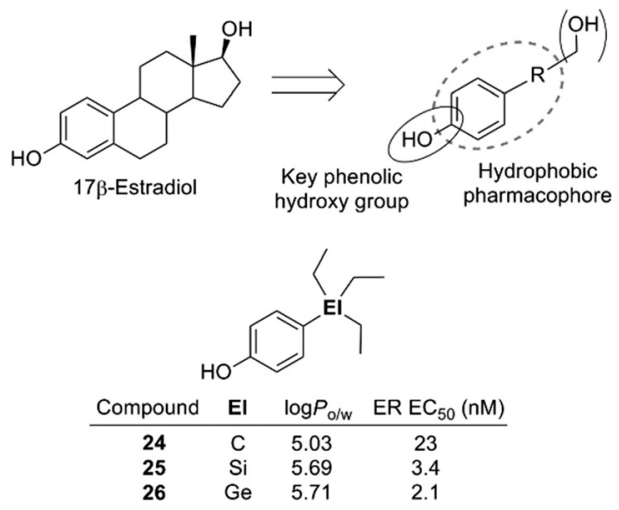

Fig. 7 Pharmacophore of estrogen receptor ligands and structure of ER ligands. 

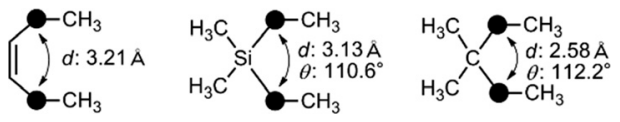

Fig. 8 Similarity in the atomic distance in cis-olefin and silane.

double bond, exhibited a moderate PPAR $\alpha$ agonistic activity as well as PPAR $\delta$ agonistic activity (Fig. 9). ${ }^{26}$ Siliconcontaining lipids could be an interesting category of biologically active compounds.

In addition to cis-olefin, a cis-amide moiety could be replaced by a silyl functionality. The cis-amide-containing tricyclic heterocycle phenanthridin-6-one is a versatile scaffold for medicinal chemistry, and various bioactive phenanthridin-6one derivatives, including nuclear liver $\mathrm{X}$ receptor (LXR) ligands and ROR ligands, have been reported. ${ }^{27}$ In the case of the ROR ligands, docking simulation suggested that the amide moiety of phenanthridin-6-one was surrounded by hydrophobic amino acids and did not contribute to hydrogen bonding to the receptor. Therefore, the cis-amide moiety of phenanthridin-6-one-based ROR ligands could be replaced by a hydrophobic silyl functionality. Structural development afforded dibenzosilole derivatives such as 28a that exhibited a significant ROR inverse agonist activity, nearly equal to that of the parent phenanthridin-6-one derivatives (Fig. 10). ${ }^{28}$ Silicon-containing heterocycles could be also versatile scaffolds for biologically active compounds.

\section{Hydrophobic boron clusters}

Higher boranes (boron hydrides) form clusters, and closo-borane compounds $\left(\left[\mathrm{B}_{n} \mathrm{H}_{n}\right]^{2-}\right)$ have closed structures such as octahedron and icosahedron. Since the carbon atom has one more valence electron than the boron atom, the $\mathrm{C}-\mathrm{H}$ unit is isoelectronic and isolobal with $[\mathrm{B}-\mathrm{H}]^{-}$. Thus, the two-carbon-containing analogs of $\left[\mathrm{B}_{n} \mathrm{H}_{n}\right]^{2-}$ are the neutral compounds $\mathrm{C}_{2} \mathrm{~B}_{n-2} \mathrm{H}_{n}$, and these carbon-containing boron clusters are called carboranes or carbaboranes. ${ }^{29}$ The icosahedral twelve-vertex dicarba-closododecaboranes $\left(\mathrm{C}_{2} \mathrm{~B}_{10} \mathrm{H}_{12}\right)$ have been extensively investigated, and are usually simply called carboranes. Carboranes have high chemical and thermal stability and exhibit high hydrophobicity,

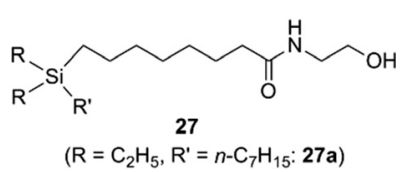

Fig. 9 Silicon-containing ethanolamide lipids as PPAR ligands.

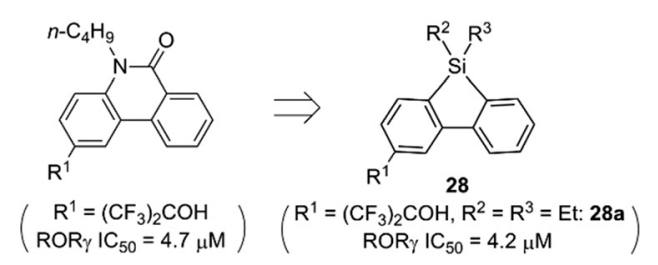

Fig. 10 Design of dibenzosilole derivatives as ROR inverse agonists. as well as having a bulky spherical structure. ${ }^{30,31}$ Fig. 11 shows the structure of three isomers of carborane, namely ortho- $(o-)$, meta- $(m-)$ and para- ( $p$-) carboranes (Fig. 11).

In the field of medicinal chemistry, carboranes have been investigated as boron carriers for boron neutron capture therapy (BNCT) of cancer, based on the nuclear reaction of boron-10 $\left({ }^{10} \mathrm{~B}\right)$ with thermal neutrons to generate high linear energy transfer (LET) particles having destructive path lengths of only approximately one cell diameter (thermal neutrons themselves cause little damage because of their low energy). BNCT is considered a promising modality for treatment of brain cancer and prostate cancer. ${ }^{32,33}$

On the other hand, development of carborane-based biologically active compounds utilizing the characteristic features of carboranes, i.e. high hydrophobicity and spherical geometry, is at an early stage. ${ }^{34} \mathrm{~A}$ milestone in the field of carborane-based biologically active compounds was the development of the carboranylphenol derivatives as ER $\alpha$ superagonists by Endo and co-workers. $p$-Carboranylphenol derivative 29 exhibited a potent ER $\alpha$ agonistic activity exceeding that of endogenous estrogen $17 \beta$-estradiol $\left(E_{2}\right)$. A simple carboranylphenol 30 also exhibited a significant ER $\alpha$ agonistic activity comparable to that of $\mathrm{E}_{2}$ (Fig. 12). ${ }^{35,36}$ These results suggested that the carborane cage can function as a hydrophobic core structure as effectively as hydrocarbons (such as a steroidal skeleton).

Based on the structural features of developed ER modulators tamoxifen and raloxifene, a series of carborane-based bisphenols and related derivatives were developed. Bis(4hydroxyphenyl)-o-carborane 31, which exhibited an ER $\alpha$ antagonistic activity in vitro, is one of the most intensively investigated carborane derivatives. Interestingly, compound 31 significantly prevented bone loss in ovariectomized mice (OVX mice), suggesting that it acts as a selective estrogen receptor modulator (SERM) in vivo. ${ }^{37} \mathrm{~m}$-Carborane-based bisphenol is also a versatile scaffold for development of novel ER modulators. Simple bisphenol compound 32 exhibited a potent ER $\alpha$ agonistic activity. Modification of one of the phenolic hydroxyl

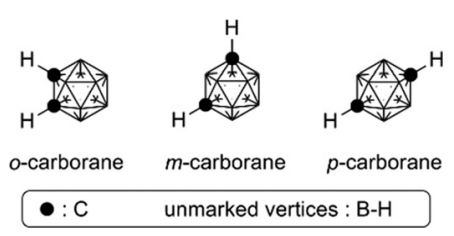

Fig. 11 Structure of the three isomers of dicarba-closo-dodecaboranes (carboranes).

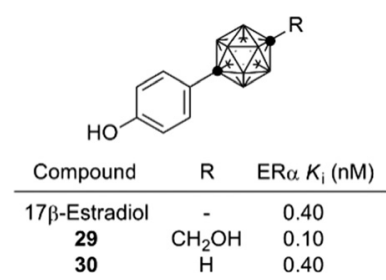

Fig. 12 Structure and activity of carborane-based potent ER agonists. 
groups of compound 32 resulted in significant changes of the activity. 3-Dimethylaminopropyl analog 34 exhibited a full agonistic activity, whereas 2-dimethylaminoethyl analog 33 exhibited a weak $\mathrm{ER} \alpha$ partial agonistic activity. 2-Piperidinylethyl derivative 35 also exhibited an ER $\alpha$ partial agonistic activity. Surprisingly, compound 36, a $B$-phenyl $o$-carborane derivative having almost the same structure as 32, exhibited no significant activity. ${ }^{38,39}$ Thus, the difference in hydrophobicity between these two isomers significantly altered the biological activity. $p$-Carborane-based derivatives 37 exhibited an ER $\alpha$ agonistic activity (Fig. 13). ${ }^{40}$ Carboranes have been also used for the development of ER $\beta$ selective ligands such as 38-41(Fig. 14). ${ }^{41,42}$

$o$-Carborane analogs of tamoxifen were also synthesized. Though isomerization of compound 42 to 43 was reported (Fig. 15), the carborane derivatives are less susceptible to degradation than the parent tamoxifen. Carborane analogs 42 and 43 showed a growth-inhibitory activity toward human breast cancer cell lines. ${ }^{43}$

Following the success in obtaining ER ligands, development of other nuclear steroid hormone receptor ligands was investigated. The androgen receptor (AR) is a nuclear receptor for androgens such as steroid hormones testosterone and dihydrotestosterone (DHT). Based on the findings during the development of carborane-containing ER ligands, cyclohexylcarborane derivatives such as $\mathbf{4 4}$ were designed and synthesized as AR ligand candidates. The cyclohexylcarborane derivatives exhibited a moderate AR antagonistic activity. ${ }^{\mathbf{4 4}}$ On the other hand, phenylcarborane derivatives such as $\mathbf{4 5}$, which were designed as hybrids of 44 and developed AR antagonists such as flutamide and bicalutamide, exhibited a potent AR antagonistic activity. ${ }^{45}$ These results indicate that the phenylcarborane substructure is a promising scaffold for development of nuclear steroid hormone receptor ligands. Based on the structure of compound 45, a series of carborane-based AR antagonists have been developed. Ether, sulfide and sulfone derivatives such as 46 (ref. 46) and amide
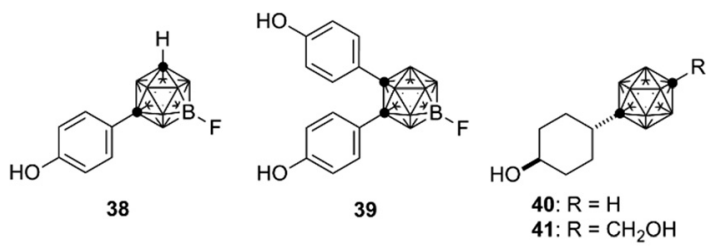

\begin{tabular}{cccc} 
Compound & ER $\alpha$ RBA & ER $\beta$ RBA & Selectivity $(E R \beta / E R \alpha)$ \\
\hline $\mathbf{2 9}$ & 160 & 220 & 1.4 \\
$\mathbf{3 1}$ & 68 & 46 & 0.68 \\
$\mathbf{3 8}$ & 4.8 & 41 & 8.5 \\
$\mathbf{3 9}$ & 15 & 16 & 1.1 \\
$\mathbf{4 0}$ & 0.0052 & 0.29 & 56 \\
$\mathbf{4 1}$ & 1.4 & 9.8 & 7.0
\end{tabular}

Fig. 14 Structure and biological activity of some ER $\beta$ ligands. RBA: Relative binding affinity with respect to that of estradiol taken as 100.

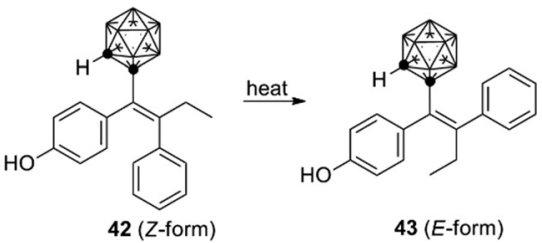

Fig. 15 Structure and isomerization of the 0 -carborane analog of hydroxytamoxifen (Valliant et al.).

derivatives such as 47 (ref. 47) were developed as antiandrogens effective toward T887A-mutated AR. T877A mutation is one of the major cause of castration-resistant prostate cancer (CRPC), ${ }^{48,49}$ and therefore these carborane-based AR antagonists are possible lead compounds for development of drugs to treat CRPC (Fig. 16).

During the development of AR antagonists, incorporation of carborane species other than dicarba-closo-dodecaboranes $\left(\mathrm{C}_{2} \mathrm{~B}_{10} \mathrm{H}_{12}\right)$ was also investigated. For example, ten-vertex p-carborane, specifically 1,10-dicarba-closo-decaborane $\left(\mathrm{C}_{2} \mathrm{~B}_{8} \mathrm{H}_{10}\right)$, is one of the smaller dicarba-closo-boranes, bearing a hydrophobic surface with ten vertices. Ten-vertex $p$-carborane
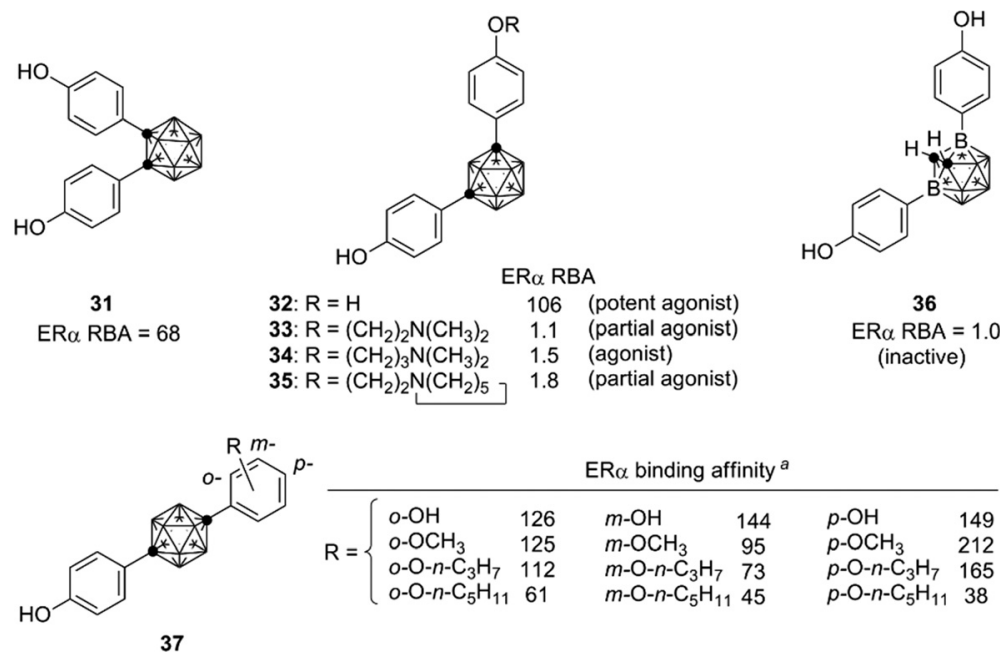

ER $\alpha$ binding affinity ${ }^{a}$

$\begin{array}{lcll}m-\mathrm{OH} & 144 & p-\mathrm{OH} & 149 \\ m-\mathrm{OCH} H_{3} & 95 & p-\mathrm{OCH}_{3} & 212 \\ m-\mathrm{O}-n-\mathrm{C}_{3} \mathrm{H}_{7} & 73 & p-\mathrm{O}-n-\mathrm{C}_{3} \mathrm{H}_{7} & 165 \\ m-\mathrm{O}-n-\mathrm{C}_{5} \mathrm{H}_{11} & 45 & p-\mathrm{O}-n-\mathrm{C}_{5} \mathrm{H}_{11} & 38\end{array}$

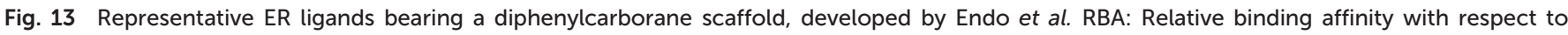

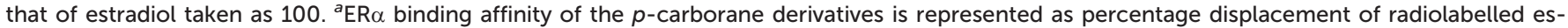
tradiol specific binding to $\mathrm{hER} \alpha$ by each compound with a concentration of $4 \mathrm{nM}$ (estradiol taken as 100). 

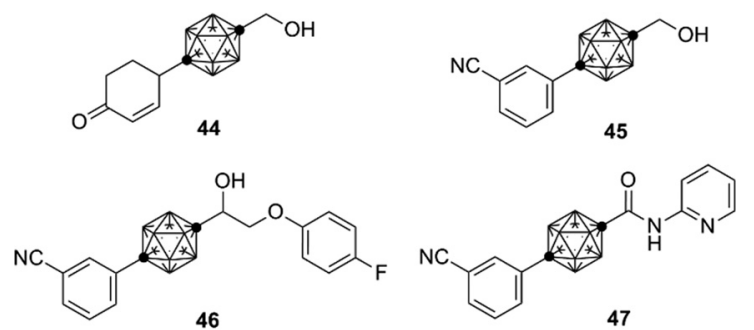

46

47

\begin{tabular}{ccc} 
Compound & $\begin{array}{c}\mathrm{SC}-3 \text { (wtAR) } \\
\mathrm{IC}_{50}(\mu \mathrm{M})\end{array}$ & $\begin{array}{c}\mathrm{LNCaP}(\mathrm{T} 877 \mathrm{~A}-\mathrm{AR}) \\
\mathrm{IC}_{50}(\mu \mathrm{M})\end{array}$ \\
\hline $\mathbf{4 4}$ & $\mathrm{ca} .3$ & - \\
$\mathbf{4 5}$ & 0.015 & agonist \\
$\mathbf{4 6}$ & 0.28 & 0.38 \\
$\mathbf{4 7}$ & 0.41 & 0.094
\end{tabular}

Fig. 16 Carborane-based AR antagonists.

has an overall ellipsoidal geometry and a smaller molecular volume in comparison to that of the highly symmetrical twelvevertex carboranes. Ten-vertex $p$-carborane derivative 48 exhibited an AR partial agonistic activity, while the corresponding twelvevertex carborane derivative $\mathbf{4 4}$ exhibited an AR full antagonistic activity. ${ }^{50}$ These results suggest that a slight difference in the spatial volume of the carborane cage can cause activity switching of the carborane-based AR ligands. Compound 49 exhibited potent binding affinity toward AR. In addition, compounds containing carba-closo-dodecaborate $\left(\left[\mathrm{CB}_{11} \mathrm{H}_{12}\right]^{-}\right)$, an anionic boron cluster with twelve vertices, have been developed. Compound 50 exhibits significant binding affinity toward the AR ligand-binding domain (LBD) (Fig. 17). ${ }^{51}$

AR-LBD shows high sequence identity with the nuclear progesterone receptor (PR), and thus the developed carboranebased AR ligands are also candidates as lead compounds for the development of PR ligands. Based on the structure of the developed AR antagonists, novel PR antagonists such as compounds 51 and 52, with selectivity for PR over AR and other steroid hormone receptors, were developed (Fig. 18). ${ }^{52,53}$

Development of the steroid hormone receptor ligands suggested that the phenylcarborane scaffold is a promising alternative structure to the steroidal skeleton, and the carborane cage itself could be an alternative to the CD-ring of the steroidal framework. A secosteroidal bioactive compound, $1 \alpha, 25$-dihydroxyvitamin $\mathrm{D}_{3}\left(1 \alpha, 25(\mathrm{OH})_{2} \mathrm{D}_{3}\right)$, is the endogenous ligand of the vitamin $\mathrm{D}$ receptor (VDR). Almost all developed VDR ligands with high potency have the same secosteroidal skeleton, consisting of the A-ring bearing two hydroxyl groups, a conjugated olefin moiety, the CD-ring, and a side chain. However, the studies on the ER, AR and PR ligands
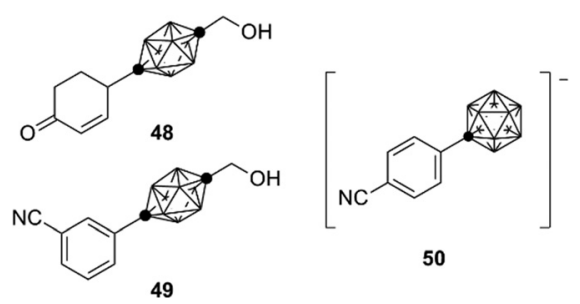

50

Fig. 17 Ten-vertex $p$-carborane derivatives and carba-closo-dodecaborate derivative.

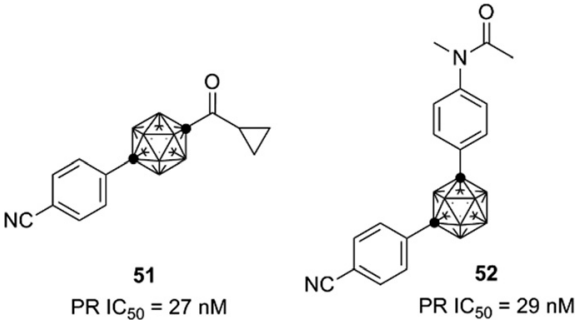

Fig. 18 Carborane-based PR antagonists.

suggested that the CD-ring of the secosteroidal structure could be replaced with a carborane cage. On the basis of these considerations, novel nonsecosteroidal VDR ligands such as compound $\mathbf{5 3}$ were developed. These VDR ligands exhibited a potent vitamin D activity, comparable to that of the natural hormone, despite their flexible structure (Fig. 19).

$\mathrm{X}$-ray crystallographic analysis indicated that the hydrophobic surface of the carborane functions as a potent hydrophobic anchor, binding the ligand to the protein surface (PDBID: 3VJS for $\boldsymbol{S}$-53 with rVDR and 3VJT for $\boldsymbol{R}-53$ with rVDR). Thus, effective hydrophobic interactions appeared to counteract the entropic disadvantage involved in the interactions of a flexible molecule. ${ }^{54}$

Based on the crystallographic analysis, the structural modification was investigated, and highly potent compounds such as 54 and 55 were developed. ${ }^{55,56}$ Compound 54 is one of the most potent nonsecosteroidal VDR ligands currently

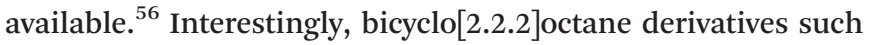
as 56 exhibited a markedly lower VDR agonistic activity than the corresponding carborane derivatives. ${ }^{57}$ These results indicate that hydrophobic interactions involving the carborane cage are essential for ligand potency (Fig. 20).

Retinoids and HIF-1 (hypoxia inducible factor 1) inhibitors containing an $o$-carborane cage as a hydrophobic substructure have also been developed. Diphenylamine-based retinoid 57 exhibited a cell differentiation-inducing activity toward human leukemia cell line HL-60 comparable to that of all-trans retinoic acid, and also exhibited a potent RAR agonistic activity with selectivity for RAR $\alpha / \beta .^{58}$ RXR antagonists were developed by structural modification of the RAR agonists. ${ }^{59}$ As for HIF-1 $\alpha$, potent carborane-containing HIF-1 $\alpha$ inhibitors, such as 58 , were developed by Nakamura and co-workers. ${ }^{60} \mathrm{~A}$ chaperone protein HSP60 was identified as a primary target molecule of compound $58,{ }^{61}$ and the $o$-carborane cage of 58 was essential for the inhibitory activity toward HSP60. ${ }^{62}$ These retinoids and HIF-1 inhibitors are expected to be versatile compounds for development of chemical probes and therapeutics for cancer (Fig. 21).

The hydrophobicity ( $\log P_{\mathrm{o} / \mathrm{w}}$ values) of carborane derivatives is significantly affected by the position of substitution at the carborane cage, as well as by the nature of the carborane isomer. ${ }^{63,64} C$-Substituted carboranyl groups are more hydrophobic than the corresponding $B$-substituted carboranyl groups. Among the $B$-substituted carboranyl groups, $m$-carboran-9-yl and $o$-carboran-9-yl groups are significantly less hydrophobic than the corresponding $C$-substituted 

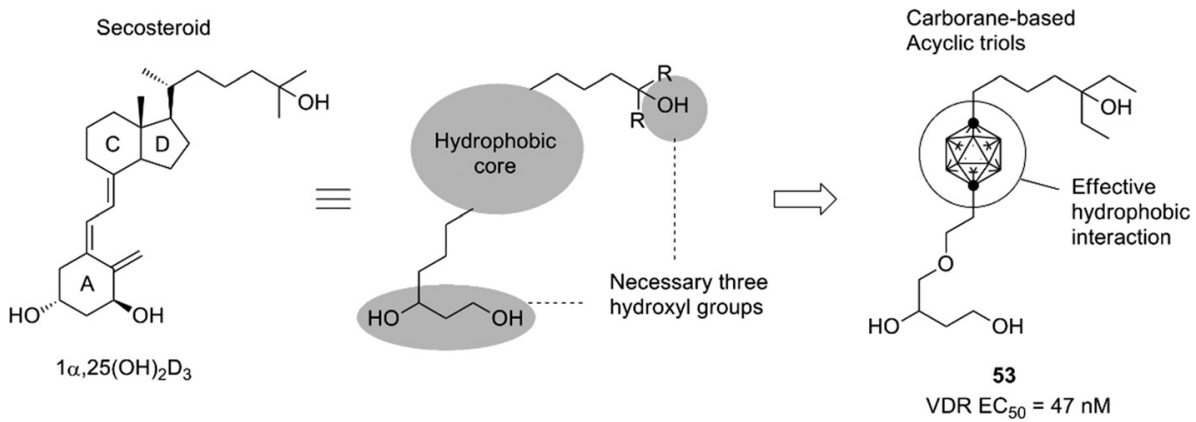

Fig. 19 Design of carborane-based nonsecosteroidal VDR ligands.
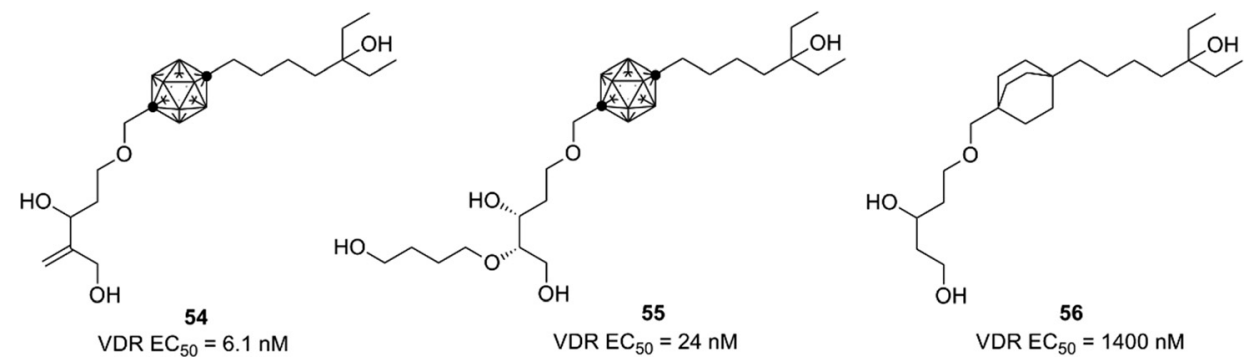

Fig. 20 VDR ligands bearing $p$-carborane or bicyclo[2.2.2] octane as the hydrophobic core structure. (All compounds were evaluated as racemic mixtures.)

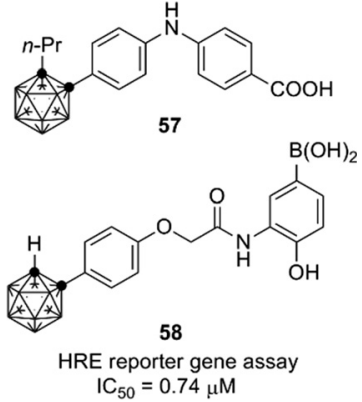

Fig. 21 Examples of carborane-containing retinoids and HIF-1 $\alpha$ inhibitors.

carboranyl groups. It is suggested that the $\mathrm{CH}$ moiety on the carborane cage has a weak hydrophilic interaction with water. This characteristic, i.e. quite different hydrophobicity with the same geometry, is a unique feature of carborane derivatives (Fig. 22).

\section{Organometallic and coordination compounds}

Since the discovery of ferrocene, a stable hydrophobic coordination compound, various applications of this sandwich compound have been investigated. Applications of metallocenes in medicinal chemistry have also been widely studied. ${ }^{65,66}$ One of the most successful examples of ferrocenecontaining compounds in medicinal chemistry is ferroquine, an antimalarial compound derived from chloroquine. ${ }^{67,68}$

In addition, a few metallocene derivatives have been developed as nuclear receptor ligands.

Among hormone-metallocene conjugates bearing metallocene as a substituent on an endogenous ligand of recep-

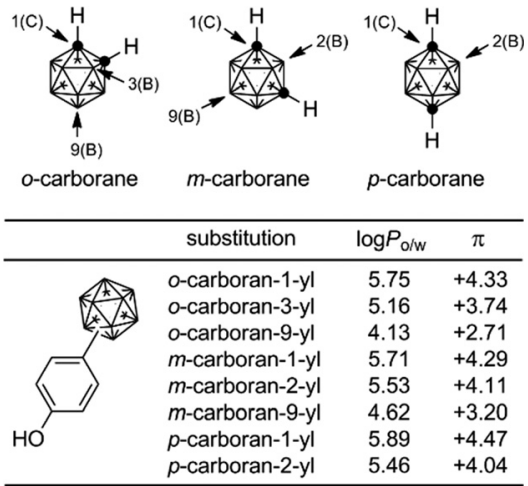

Fig. 22 Systematic determination of hydrophobicity of carboranylphenols.

tors, estradiol-metallocene conjugates including compound 59 have been most intensively investigated. Compounds bearing metallocene or other coordinated substituents at the $17 \alpha$ position, such as compounds 60-62 (Fig. 23), exhibited significant binding affinity toward ER $\alpha$ or ER $\beta .^{69-72}$ These compounds can be used as tracers in a metallo-immunoassay using metal-specific detection methods such as atomic absorption and IR spectroscopy. One example is the carbonyl metallo-immunoassay (CMIA). ${ }^{73}$ Radioactive coordination compounds, e.g. containing technetium, have also been developed as radiopharmaceuticals. $^{74}$

Ferrocene conjugates of thyroid hormones were developed for metallo-immunoassays. Ferrocene-linked triiodothyronine (T3) and thyroxin (T4) derivatives such as compounds 63 and 64 were synthesized (Fig. 24), ${ }^{75,76}$ and it was shown that the $\mathrm{T} 4$ derivatives can act as sensors of $\mathrm{T} 4$.

Ferrocene and related coordination compounds exhibit remarkable hydrophobicity, and therefore can be used as 

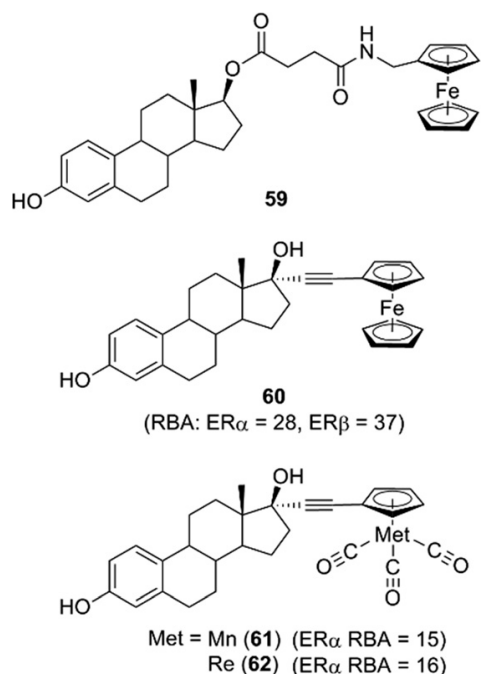

Fig. 23 Examples of conjugates of estradiol and ferrocene or other organometallic derivatives. RBA: Relative binding affinity with respect to that of estradiol taken as 100 .

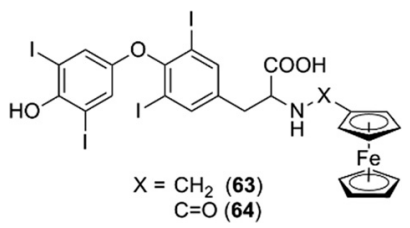

Fig. 24 Ferrocene thyroid hormone conjugates.

hydrophobic substructures of biologically active compounds. For example, ferrocifen derivatives 65, which are ferrocene analogs of tamoxifen, have been widely investigated by Jaouen and co-workers. Ferrocifens contain a ferrocene moiety as a hydrophobic substructure instead of the benzene ring of tamoxifen, and were designed as candidate SERMs. ${ }^{77}$ Ferrocifens have dual modes of action, namely they show an antiestrogenic activity toward estrogen-dependent cell line MCF-7 and an inhibitory activity toward estrogen-independent MDA-
MB231 cell line. ${ }^{78,79}$ On the other hand, ruthenocene analogs 66 and osmosene analogs 67 of ferrocifens exhibited a low activity toward MDA-MB231. ${ }^{80,81}$ Ferrociphenol (68), a bisphenol derivative containing a ferrocene moiety as a hydrophobic substructure, exhibited moderate binding affinities toward $E R \alpha / \beta$ and a potent cell proliferation-inhibitory activity toward both MCF-7 and MDA-MB231 cell lines. On the other hand, a ferrocene analog of diethylstilbestrol 71, which is a regioisomer of ferrociphenol 68, scarcely affected the proliferation of these cell lines. ${ }^{82}$ Ruthenocene analog 69 and osmocene analog 70 of ferrociphenol also exhibited a quite low anti-proliferative activity toward these cell lines (Fig. 25). ${ }^{81}$

Further structural development has been investigated, including the ansa series $(72,73),{ }^{83}$ hydroxypropyl series and the corresponding quinone methide species (Fig. 26), ${ }^{84}$ and the mechanism of action of ferrocifens has been intensively studied. It was proposed that cytotoxic quinone methide $\mathbf{7 4}$ is formed by oxidation of 68 and that the redox properties of ferrocene contribute to the oxidation process. Changing the metal atom can significantly alter the redox properties. Experiments using quinone methide derivatives suggested that thioredoxin reductases are possible targets of the cytotoxicity of ferrocifens. ${ }^{85}$

In addition to antiestrogens, ferrocene-containing antiandrogens have been developed. Several ferrocene conjugates of nilutamide, such as 75 and 76, were synthesized based on the structure of nilutamide, a representative nonsteroidal AR antagonist. ${ }^{86}$ Among them, compound 76 exhibited a potent anti-androgenic activity toward the androgen-dependent LNCaP cell line, as well as a potent proliferation-inhibitory activity toward the androgen-independent PC-3 cell line. Compound 77 bearing an anisyl moiety instead of ferrocene also showed a significant activity toward both cell lines. Therefore, in contrast to ferrocifens, the cytotoxic effect of compound $\mathbf{7 6}$ is probably attributable to the aromatic or hydrophobic character of ferrocene, rather than to its redox characteristics (Fig. 27).

Jaouen and co-workers determined the hydrophobicity parameter, $\log P_{\mathrm{o} / \mathrm{w}}$, of ferrocifens and nilutamide conjugates.

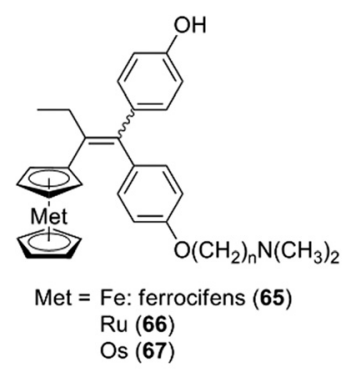

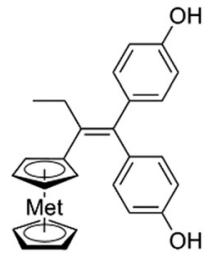

Met $=$ Fe: ferrociphenol $(68)$ Ru (69)
Os (70)

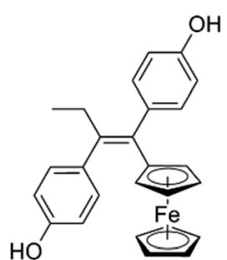

71

\begin{tabular}{lccc} 
Compound & $\begin{array}{c}\text { MCF-7 } \\
\mathrm{IC}_{50}(\mu \mathrm{M})\end{array}$ & $\begin{array}{c}\text { MDA-MB-231 } \\
\mathrm{IC}_{50}(\mu \mathrm{M})\end{array}$ & $\log P_{\mathrm{o} / \mathrm{w}}$ \\
\hline $\mathbf{6 5}(\mathrm{n}=3)$ & 0.8 & 0.5 & $4.3(Z), 4.5(E)$ \\
$\mathbf{6 6}(\mathrm{n}=3)$ & 2.4 & 1.99 & 4.8 \\
$\mathbf{6 7}(\mathrm{n}=3)$ & 2.9 & 2.7 & 4.3 \\
$\mathbf{6 8}$ & 0.9 & 0.60 & 5.0 \\
$\mathbf{6 9}$ & $\mathrm{ca} .30$ & 27 & 5.4 \\
$\mathbf{7 0}$ & $>30$ & 29 & 5.2
\end{tabular}

Fig. 25 Structure and properties of ferrocifen, ferrociphenol and related compounds. 


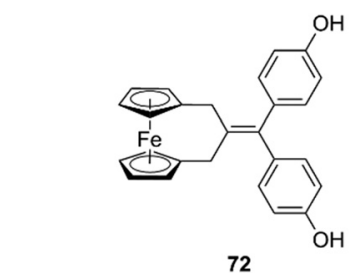

72

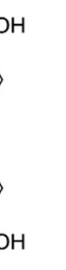

\begin{tabular}{ccc} 
Compound & ER $\alpha$ RBA & ER $\beta$ RBA \\
\hline $\mathbf{6 8}$ & 9.6 & 16.3 \\
$\mathbf{7 2}$ & 7.6 & 15.4 \\
$\mathbf{7 3}$ & 7.2 & 4.84
\end{tabular}

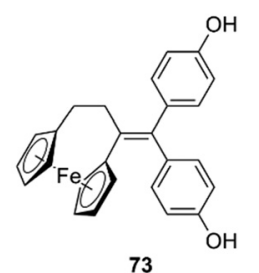

73

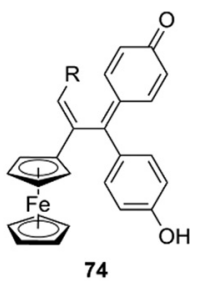

74

\begin{tabular}{ccc}
$\begin{array}{c}\text { MDA-MB-231 } \\
\mathrm{IC}_{50}(\mu \mathrm{M})\end{array}$ & $\begin{array}{c}\mathrm{PC}-3 \\
\mathrm{IC}_{50}(\mu \mathrm{M})\end{array}$ & $\log P_{\mathrm{o} / \mathrm{w}}$ \\
\hline 0.64 & 0.7 & 5.0 \\
0.96 & 1.08 & 4.8 \\
0.09 & 0.094 & 4.6
\end{tabular}

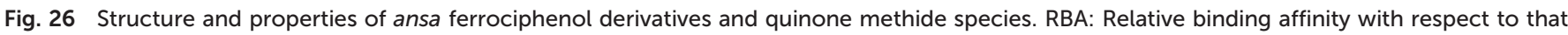
of estradiol taken as 100 .

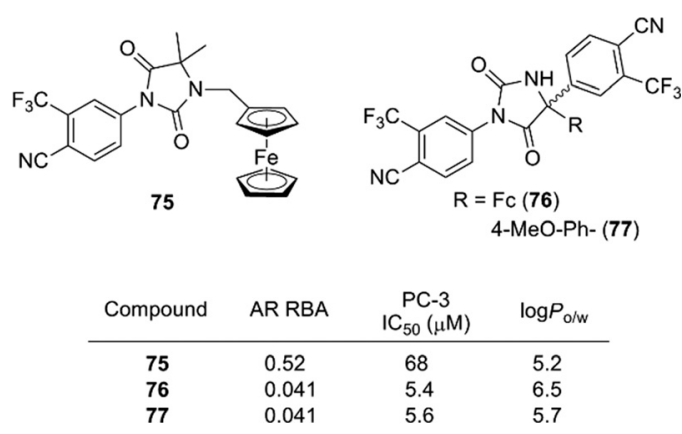

Fig. 27 Ferrocene derivatives of AR antagonist nilutamide (Jaouen et al.). RBA: Relative binding affinity with respect to that of DHT taken as 100.

Ferrociphenol 68 showed a $\log P_{\mathrm{o} / \mathrm{w}}$ value of 5.0, which is larger by 0.6 than that of the corresponding phenyl analog. ${ }^{81}$ The difference in $\log P_{\mathrm{o} / \mathrm{w}}$ between 76 (6.5) and $77(5.7)$ is $0.8{ }^{86}$ Compounds with an ansa-ferrocene moiety have somewhat smaller $\log P_{\mathrm{o} / \mathrm{w}}$ values (compound $72 ; 4.8$, compound $73 ; 4.6)$ than the parent acyclic ferrociphenol $68(5.0) .{ }^{83}$ The hydrophobicity of ruthenocene derivative 69 (5.4) and osmocene derivative 70 (5.2) is somewhat larger than that of ferrociphenol, and rhenium carbonyl derivatives of ferrocifen are more hydrophobic than the corresponding ferrocene ana$\operatorname{logs}{ }^{74,82}$ Thus, ferrocene and other hydrophobic coordination species can serve as hydrophobic moieties with various functions, such as redox promotion and immunoassay labels.

\section{Future perspective}

Utilization of hydrophobic substructures other than simple hydrocarbons has the potential to greatly expand the chemical space of hydrophobic pharmacophores in medicinal chemistry. Herein, the author reviews the design of transcriptional modulators, focusing on three types of inorganic and organometallic hydrophobic structural motifs. Application of silicon or germanium functionalities is one approach to enhance the biological activity and/or target selectivity. Simple $\mathrm{C} / \mathrm{Si}$ exchange, sila-substitution, has been applied not only to transcriptional modulators, but also to other targets, such as enzyme inhibitors and membrane receptor ligands, and is becoming a standard strategy. Sila-substitution has also been extended to mimicking diatomic substructures, and the introduction of hypervalent silicon functionalities is another possibility. The second approach is application of carboranes as unique spherical hydrophobic substructures. Compound libraries of carborane derivatives could be powerful tools for finding unique biological active compounds. So far, most carborane-incorporating biologically active compounds are dicarba-closo-dodecaborane derivatives, and investigation of other types of carboranes is a promising approach. In addition, there is interest in exploiting the $\mathrm{B}-\mathrm{N}$ substructure as an isostere of $\mathrm{C}=\mathrm{C}$ double bonds. ${ }^{87}$ For example, it was recently proposed that benzazaborinine can function as a bioisostere of naphthalene. ${ }^{88}$ In the third category of metallocenes, the redox properties of the metal atom play a major role. Metallocenes are not only merely hydrophobic substructures, but also functional chemical species, and may allow the development of polyfunctional bioactive compounds. One common issue to be addressed in applying all of the above hydrophobic fragments in drug discovery is their influence on ADMET profiles. Though some in vivo characterisation has been investigated in a few cases including compounds 2 (ref. 10) and $31,{ }^{37}$ and in vitro metabolism of ferrocifens has been also investigated, ${ }^{89}$ there is a great need for systematic investigation of metabolic and toxicity profiles. Overall, novel hydrophobic substructures have great potential for enlarging the chemical space of hydrophobic pharmacophores in the field of medicinal chemistry.

\section{Notes and references}

1 The Practice of Medicinal Chemistry, ed. C. G. Wermuth, Academic Press, Cambridge, 2nd edn, 2003.

2 A. K. Franz and S. O. Wilson, J. Med. Chem., 2013, 56, 388-405.

3 G. A. Showell and J. S. Mills, Drug Discovery Today, 2003, 8, 551-556.

4 J. S. Mills and G. A. Showell, Expert Opin. Invest. Drugs, 2004, 13, 1149-1157.

5 S. Gately and R. West, Drug Dev. Res., 2007, 68, 156-163.

6 H. Kagechika and K. Shudo, J. Med. Chem., 2005, 48, 5875-5883. 
7 H. Kagechika, E. Kawachi, Y. Hashimoto, T. Himi and K. Shudo, J. Med. Chem., 1988, 31, 2182-2192.

8 H. Kagechika, E. Kawachi, Y. Hashimoto and K. Shudo, J. Med. Chem., 1989, 32, 834-840.

9 T. Yamakawa, H. Kagechika, E. Kawachi, Y. Hashimoto and K. Shudo, J. Med. Chem., 1990, 33, 1430-1437.

10 K. B. Higginbotham, R. Lozano, T. Brown, Y. Z. Patt, T. Arima, J. L. Abbruzzese and M. B. Thomas, J. Cancer Res. Clin. Oncol., 2008, 134, 1325-1335.

11 K. Ohnishi, Int. J. Clin. Oncol., 2007, 12, 313-317.

12 A. Takeshita, K. Shinagawa, M. Adachi, T. Ono, T. Kiguchi and T. Naoe, Expert Opin. Orphan Drugs, 2014, 2, 961-969.

13 M. F. Boehm, L. Zhang, B. A. Badea, S. K. White, D. E. Mais, E. Berger, C. M. Suto, M. E. Goldman and R. A. Heyman, J. Med. Chem., 1994, 37, 2930-2941.

14 T. Tanaka and L. M. De Luca, Cancer Res., 2009, 69, 4945-4947.

15 R. Tacke, V. Müller, M. W. Büttner, W. P. Lippert, R. Bertermann, J. O. Daiß, H. Khanwalkar, A. Furst, C. Gaudon and H. Gronemeyer, ChemMedChem, 2009, 4, 1797-1802.

16 M. W. Büttner, C. Burschka, J. O. Daiss, D. Ivanova, N. Rochel, S. Kammerer, C. Peluso-Iltis, A. Bindler, C. Gaudon, P. Germain, D. Moras, H. Gronemeyer and R. Tacke, ChemBioChem, 2007, 8, 1688-1699.

17 J. O. Daiss, C. Burschka, J. S. Mills, J. G. Montana, G. A. Showell, I. Fleming, C. Gaudon, D. Ivanova, H. Gronemeyer and R. Tacke, Organometallics, 2005, 24, 3192-3199.

18 W. P. Lippert, C. Burschka, K. Götz, M. Kaupp, D. Ivanova, C. Gaudon, Y. Sato, P. Antony, N. Rochel, D. Moras, H. Gronemeyer and R. Tacke, ChemMedChem, 2009, 4, 1143-1152.

19 H. Toyama, M. Nakamura, M. Nakamura, Y. Matsumoto, M. Nakagomi and Y. Hashimoto, Bioorg. Med. Chem., 2014, 22, 1948-1959.

20 M. F. Boehm, P. Fitzgerald, A. Zou, M. G. Elgort, E. D. Bischoff, L. Mere, D. F. Mais, R. P. Bissonnette, R. A. Heyman, A. M. Nadzan, M. Reichman and E. A. Allegretto, Chem. Biol., 1999, 6, 265-275.

21 S. Hosoda, A. Tanatani, K. Wakabayashi, Y. Nakano, H. Miyachi, K. Nagasawa and Y. Hashimoto, Bioorg. Med. Chem. Lett., 2005, 15, 4327-4331.

22 M. Nakamura, M. Makishima and Y. Hashimoto, Bioorg. Med. Chem., 2013, 21, 1643-1651.

23 S. Fujii, Y. Miyajima, H. Masuno and H. Kagechika, J. Med. Chem., 2013, 56, 160-166.

24 D. Kajita, M. Nakamura, Y. Matsumoto, M. Makishima and Y. Hashimoto, Bioorg. Med. Chem., 2014, 22, 2244-2252.

25 G. Astarita, B. Di Giacomo, S. Gaetani1, F. Oveisi, T. R. Compton, S. Rivara, G. Tarzia, M. Mor and D. Piomelli, J. Pharmacol. Exp. Ther., 2006, 312, 563-570.

26 D. Kajita, M. Nakamura, Y. Matsumoto, M. Ishikawa, Y. Hashimoto and S. Fujii, Bioorg. Med. Chem. Lett., 2015, 25, 3350-3354.

27 Y. Nishiyama, M. Nakamura, T. Misawa, M. Nakagomi, M. Makishima, M. Ishikawa and Y. Hashimoto, Bioorg. Med. Chem., 2014, 22, 2799-2808.
28 H. Toyama, M. Nakamura, Y. Hashimoto and S. Fujii, Bioorg. Med. Chem., 2015, 23, 2982-2988.

29 The borane, carborane, carbocation continuum, ed. J. Casanova, Wiley Interscience, New York, 1998.

30 V. I. Bregadze, Chem. Rev., 1992, 92, 209-223.

31 A. H. Soloway, W. Tjarks and J. G. Barnum, Chem. Rev., 1998, 98, 1515-1562.

32 M. F. Hawthorne, Angew. Chem., Int. Ed. Engl., 1993, 32, 950-984.

33 G. L. Locher, Am. J. Roentgenol., Radium Ther. Nucl. Med., 1936, 36, 1-13.

34 F. Issa, M. Kassiou and L. M. Rendina, Chem. Rev., 2011, 111, 5701-5722.

35 Y. Endo, T. Iijima, Y. Yamakoshi, M. Yamaguchi, H. Fukasawa and K. Shudo, J. Med. Chem., 1999, 42, 1501-1504.

36 Y. Endo, T. Iijima, Y. Yamakoshi, H. Fukasawa, C. Miyaura, M. Inada, A. Kubo and A. Itai, Chem. Biol., 2001, 8, 341-355.

37 Y. Endo, T. Yoshimi and C. Miyaura, Pure Appl. Chem., 2003, 75, 1197-1205.

38 T. Ogawa, K. Ohta, T. Yoshimi, H. Yamazaki, T. Suzuki, S. Ohta and Y. Endo, Bioorg. Med. Chem. Lett., 2006, 16, 3943-3946.

39 K. Ohta, T. Ogawa, T. Suzuki, S. Ohta and Y. Endo, Bioorg. Med. Chem., 2009, 17, 7958-7963.

40 T. Ogawa, K. Ohta, T. Iijima, T. Suzuki, S. Ohta and Y. Endo, Bioorg. Med. Chem., 2009, 17, 1109-1117.

41 K. Ohta, T. Ogawa, A. Kaise and Y. Endo, Bioorg. Med. Chem. Lett., 2013, 23, 6555-6558.

42 K. Ohta, T. Ogawa, A. Oda, A. Kaise and Y. Endo, Bioorg. Med. Chem. Lett., 2015, 25, 4174-4178.

43 M. L. Beer, J. Lemon and J. F. Valliant, J. Med. Chem., 2010, 53, 8012-8020.

44 S. Fujii, Y. Hashimoto, T. Suzuki, S. Ohta and Y. Endo, Bioorg. Med. Chem. Lett., 2005, 15, 227-230.

45 S. Fujii, T. Goto, K. Ohta, Y. Hashimoto, T. Suzuki, S. Ohta and Y. Endo, J. Med. Chem., 2005, 48, 4654-4662.

46 T. Goto, K. Ohta, S. Fujii, S. Ohta and Y. Endo, J. Med. Chem., 2010, 53, 4917-4926.

47 S. Fujii, A. Yamada, K. Tomita, M. Nagano, T. Goto, K. Ohta, T. Harayama, Y. Endo and H. Kagechika, Med. Chem. Commun., 2011, 2, 877-880.

48 H. I. Scher, G. Steineck and W. K. Kelly, Urology, 1995, 46, 142-148.

49 H. Miyamoto, M. M. Rahman and C. Chang, J. Cell. Biochem., 2003, 91, 3-12.

50 S. Fujii, K. Ohta, T. Goto, A. Oda, H. Masuno, Y. Endo and H. Kagechika, Med. Chem. Commun., 2012, 3, 680-684.

51 J. Kanazawa, R. Takita, A. Jankowiak, S. Fujii, H. Kagechika, D. Hashizume, K. Shudo, P. Kaszyński and M. Uchiyama, Angew. Chem., Int. Ed., 2013, 52, 8017-8021.

52 S. Fujii, A. Yamada, E. Nakano, Y. Takeuchi, S. Mori, H. Masuno and H. Kagechika, Eur. J. Med. Chem., 2014, 84, 264-277.

53 S. Fujii, E. Nakano, N. Yanagida, S. Mori, H. Masuno and H. Kagechika, Bioorg. Med. Chem., 2014, 22, 5329-5337.

54 S. Fujii, H. Masuno, Y. Taoda, A. Kano, A. Wongmayura, M. Nakabayashi, N. Ito, M. Shimizu, E. Kawachi, T. Hirano, Y. 
Endo, A. Tanatani and H. Kagechika, J. Am. Chem. Soc., 2011, 133, 20933-20941.

55 S. Fujii, A. Kano, H. Masuno, C. Songkram, E. Kawachi, T. Hirano, A. Tanatani and H. Kagechika, Bioorg. Med. Chem. Lett., 2014, 24, 4515-4519.

56 S. Fujii, R. Sekine, A. Kano, H. Masuno, C. Songkram, E. Kawachi, T. Hirano, A. Tanatani and H. Kagechika, Bioorg. Med. Chem., 2014, 22, 5891-5901.

57 A. Wongmayura, S. Fujii, S. Ito, A. Kano, Y. Taoda, E. Kawachi, H. Kagechika and A. Tanatani, Bioorg. Med. Chem. Lett., 2012, 22, 1756-1760.

58 Y. Endo, T. Iijima, K. Yaguchi, E. Kawachi, N. Inoue, H. Kagechika, A. Kubo and A. Itai, Bioorg. Med. Chem. Lett., 2001, 11, 1307-1311.

59 K. Ohta, T. Iijima, E. Kawachi, H. Kagechika and Y. Endo, Bioorg. Med. Chem. Lett., 2004, 14, 5913-5918.

60 K. Shimizu, M. Maruyama, Y. Yasui, H. Minegishi, H. S. Ban and H. Nakamura, Bioorg. Med. Chem. Lett., 2010, 20, 1453-1456.

61 H. S. Ban, K. Shimizu, H. Minegishi and H. Nakamura, J. Am. Chem. Soc., 2010, 132, 11870-11871.

62 H. Nakamura, Y. Yasui, M. Maruyama, H. Minegishi, H. S. Ban and S. Sato, Bioorg. Med. Chem. Lett., 2013, 23, 806-810.

63 K. Yamamoto and Y. Endo, Bioorg. Med. Chem. Lett., 2001, 11, 2389-2392.

64 Y. Endo, K. Yamamoto and H. Kagechika, Bioorg. Med. Chem. Lett., 2003, 13, 4089-4092.

65 D. R. van Staveren and N. Metzler-Nolte, Chem. Rev., 2004, 104, 5931-5985.

66 G. Gasser, I. Ott and N. Metzler-Nolte, J. Med. Chem., 2011, 54, 3-25.

67 C. Biot, G. Glorian, L. A. Maciejewski, J. S. Brocard, O. Domarle, G. Blampain, P. Millet, A. J. Georges, H. Abessolo and D. Dive, J. Med. Chem., 1997, 40, 3715-3718.

68 D. Dive and C. Biot, ChemMedChem, 2008, 3, 383-391.

69 M. Cais, S. Dani, Y. Eden, O. Gandolfi, M. Horn, E. E. Isaacs, Y. Josephy, Y. Saar, E. Slovin and L. Snarsky, Nature, 1977, 270, 534-535.

70 M. Cais, E. Slovin and L. Snarsky, J. Organomet. Chem., 1978, 160, 223-230.

71 D. Osella, C. Nervi, F. Galeotti, G. Cavigiolio, A. Vessières and G. Jaouen, Helv. Chim. Acta, 2001, 84, 3289-3298.
72 S. Top, H. El Hafa, A. Vessières, J. Quivy, J. Vaissermann, D. W. Hughes, M. J. McGlinchey, J.-P. Mornon, E. Thoreau and G. Jaouen, J. Am. Chem. Soc., 1995, 117, 8372-8380.

73 A. Vessières, J. Organomet. Chem., 2013, 734, 3-16.

74 S. Top, A. Vessières, P. Pigeon, M.-N. Rager, M. Huché, E. Salomon, C. Cabestaing, J. Vaissermann and G. Jaouen, ChemBioChem, 2004, 5, 1104-1113.

75 G. A. Robinson, G. Martinazzo and G. C. Forrest, J. Immunoassay, 1986, 7, 1-15.

76 T. Yao and G. A. Rechnitz, Biosensors, 1988, 3, 307-312.

77 S. Top, J. Tang, A. Vessières, D. Carrez, C. Provot and G. Jaouen, Chem. Commun., 1996, 955-956.

78 S. Top, A. Vessières, C. Cabestaing, I. Laios, G. Leclercq, C. Provot and G. Jaouen, J. Organomet. Chem., 2001, 637-639, 500-506.

79 S. Top, A. Vessières, G. Leclercq, J. Quivy, J. Tang, J. Vaissermann, M. Huché and G. Jaouen, Chem. - Eur. J., 2003, 9, 5223-5236.

80 P. Pigeon, S. Top, A. Vessières, M. Huché, E. A. Hillard, E. Salomon and G. Jaouen, J. Med. Chem., 2005, 48, 2814-2821.

81 H. Z. S. Lee, O. Buriez, F. Chau, E. Labbé, R. Ganguly, C. Amatore, G. Jaouen, A. Vessières, W. K. Leong and S. Top, Eur. J. Inorg. Chem., 2015, 4217-4226.

82 A. Vessières, S. Top, P. Pigeon, E. Hillard, L. Boubeker, D. Spera and G. Jaouen, J. Med. Chem., 2005, 48, 3937-3940.

83 D. Plażuk, A. Vessières, E. A. Hillard, O. Buriez, E. Labbé, P. Pigeon, M.-A. Plamont, C. Amatore, J. Zakrzewski and G. Jaouen, J. Med. Chem., 2009, 52, 4964-4967.

84 Y. Wang, P. Pigeon, S. Top, M. J. McGlinchey and G. Jaouen, Angew. Chem., Int. Ed., 2015, 54, 10230-10233.

85 A. Citta, A. Folda, A. Bindoli, P. Pigeon, S. Top, A. Vessières, M. Salmain, G. Jaouen and M. P. Rigobello, J. Med. Chem., 2014, 57, 8849-8859.

86 O. Payen, S. Top, A. Vessières, E. Brulé, M.-A. Plamont, M. J. McGlinchey, H. Müller-Bunz and G. Jaouen, J. Med. Chem., 2008, 51, 1791-1799.

87 P. G. Campbell, A. J. V. Marwitz and S.-Y. Liu, Angew. Chem., Int. Ed., 2012, 51, 6074-6092.

88 F. J. R. Rombouts, F. Tovar, N. Austin, G. Tresadern and A. A. Trabanco, J. Med. Chem., 2015, 58, 9287-9295.

89 M.-A. Richard, D. Hamels, P. Pigeon, S. Top, P. M. Dansette, H. Z. S. Lee, A. Vessières, D. Mansuy and G. Jaouen, ChemMedChem, 2015, 10, 981-990. 